\title{
Transatlantica
}

Revue d'études américaines. American Studies Journal

\section{Italian Americans and the New Deal Coalition}

\section{Stefano Luconi}

\section{(2) OpenEdition}

\section{Journals}

Édition électronique

URL : http://journals.openedition.org/transatlantica/212

DOI : 10.4000/transatlantica.212

ISSN : 1765-2766

Éditeur

AFEA

\section{Référence électronique}

Stefano Luconi, «Italian Americans and the New Deal Coalition », Transatlantica [En ligne], 1 | 2006, mis en ligne le 05 avril 2006, consulté le 29 avril 2021. URL : http://journals.openedition.org/ transatlantica/212; DOI : https://doi.org/10.4000/transatlantica.212

Ce document a été généré automatiquement le 29 avril 2021.

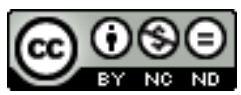

Transatlantica - Revue d'études américaines est mis à disposition selon les termes de la licence Creative Commons Attribution - Pas d'Utilisation Commerciale - Pas de Modification 4.0 International. 


\title{
Italian Americans and the New Deal Coalition
}

\author{
Stefano Luconi
}

With an estimated eligible electorate of nearly four million potential voters nationwide in the prewar decade, Italian Americans were a key component of the coalition of ethnic groups that elected Franklin D. Roosevelt to the White House in 1932 and contributed to the creation of the Democratic majority that dominated U. S. politics, at least in presidential contests, for roughly two decades (Mott ; Jensen). Conventional scholarly wisdom usually has it that most Italian Americans shifted their partisan attachment from the GOP to the Democratic party between the late 1920s and the mid 1930s (Lubell 78-83). In this view, voters from Italian background initially sided with the Republican party because they associated the GOP with economic prosperity in the aftermath of the 1893 depression that coincided with the return of a Democrat, Grover Cleveland, to the White House. They subsequently consolidated their Republican allegiance in 1920 in retaliation for Democratic President Woodrow Wilson's disregard for the claims of their ancestral country at the peace conference in Versailles at the end of World War I (Duff; Bagby 155). Conversely, voters of Italian origin began their bolt from the Republican party following New York State Governor Alfred E. Smith's bid for the White House on the Democratic ticket in 1928, as they identified themselves with a politician who rejected Prohibition and was the first presidential candidate of either major party who was not of Anglo-Saxon descent. They strengthened their Democratic affiliation in the 1930s in the wake of the Depression and in response to the labor and social legislation of the New Deal. But President Roosevelt's harsh rebuke of Italy's eleventh-hour declaration of war on France in June 1940 marked the beginning of Italian Americans' desertion of the Democratic coalition and return to the Republican camp in the war years (Rothenberg, Licht, and Newport 17-19; Martinelli 220-22 ; Barone 379-80).

2 As this argument goes, in shaping the Democratic polarization of the Italian-American electorate, ethno-cultural issues determined the partisan choice of voters of Italian ancestry in the late 1920s, while socio-economic matters influenced their political 
behavior in the following decade. Although this pattern can aptly summarize voting trends among Italian Americans in the 1920s and 1930s, in fact the timing and the mechanics of their participation in the Roosevelt coalition varied from place to place. Actually, local political conditions significantly affected the way Italian Americans cast their ballots on election day.

Most Italian immigrants, who arrived in the United States between 1881 and the enforcement of the 1921 and 1924 Quota Acts that ended the mass influx of people from Italy, were unskilled laborers who could hardly manage to make ends meet in their adoptive land. Destitute newcomers with little knowledge of electoral democracy (universal manhood suffrage was introduced as late as 1911 and women were disenfranchised until 1946 in their mother country), many Italian Americans fell easy preys to political machines and relied on partisan organizations to make a living. Like other immigrants from eastern and southern European nations, many Italians, too, bartered their votes in exchange for patronage jobs and other services-spanning from leniency in party-controlled local courts to free clothing, coal, and food baskets-that political machines were ready to provide in major cities (Martellone, "Italian Immigrants ; » Garroni).

4 As a result, in the pre-Depression years, Italian-American voters cast their ballots for the candidates of the party in power at the local level. «Little Italies » in Republican strongholds usually delivered large majorities for the GOP. For instance, on U. S. Secretary of Treasury Andrew Mellon's turf in Pittsburgh (Murray), Republican presidential candidate Calvin Coolidge received 70.5 percent of the Italian-American vote in 1924. Similarly, when Philadelphia's Republican boss William Vare ran for the U.S. Senate two year later (Salter), he carried the local Italian-American community by a 97.4 landslide (Pennsylvania State Manual, 1925-27).

5 For the same reason, however, the cities where the Democratic party controlled most positions under the spoils system in the municipal administrations and operated effective machines produced Democratic pluralities among Italian Americans in the 1920 s as well. Boston had been the seat of a powerful Democratic organization since the late XIXth century and the local «Little Italy» went Democratic even during the decade of the Republican hegemony at the national level that followed World War I, with the only exception of the 1920 backlash at Wilson's foreign policy (Martellone, Una Little Italy 495-569; Blodgett). After carrying the Italian-American community in East Boston with 53.7 percent of the vote and the «Little Italy » in the North End with 70.1 in 1920, the GOP received only 33.1 percent and 38.7 percent, respectively, in the contest for the White House four years later. In those two districts, therefore, both Smith and Roosevelt built up their 1928 and 1932 majorities among Italian-American voters (respectively, 92.6 percent and 94.5 percent in East Boston and 94.5 percent and 93.2 percent in the North End) from Democratic John Davis' 1924 pluralities. The fact that, despite his overtly pro-labor platform, Progressive presidential candidate Robert M. La Follette gained only 23.7 percent in East Boston and 18.9 percent in the North End in 1924 contributes to demonstrate that machine politics, rather than class interests, determined the party choice of most Italian Americans in Boston at least before the New Deal (Gamm 75-89).

6 In the "Solid South, » Italian Americans' Democratic attachment similarly predated the Depression of the 1930s. This was, for instance, the case of St. Louis, where they had begun to join the Democratic party en masse by the early 1920s (Mormino 179-84). 
However, in southern states, too, Italian Americans sided with local machines rather than with the Democratic party per se. As a result, for example, Louisiana's Democratic Senator Huey P. Long had numerous supporters of Italian descent, including future New Orleans' Mayor Robert Maestri, even after his own relationship with President Roosevelt soured (Jeansonne 54, 58, 75).

Political coercion of workers on the part of their employers, who usually sided with the GOP, added to machine politics and the «full dinner pail » slogan in causing Italian Americans' pre-Depression Republican allegiance. The John A. Roebling and Sons Inc. company, a wire-manufacturing plant in Trenton, New Jersey, successfully drummed up the Italian-American vote for the GOP in the 1920 s by providing jobs for the members of the city's "Little Italy " who participated in Republican activities and dismissing those who did not (Peroni 73-74). Similarly, in the same decade, subservience to the partisan orientation of their employers led the Italian-American workers of the Scovill Manufacturing Company, a metal industry in Waterbury, Connecticut, to register as Republican voters and to contribute to the election of the chairperson of their company to the state assembly on the ticket of the GOP (Fasce 236-37).

Voters' intimidation was especially influential as a determinant of party choice at the polls in company towns. In this latter milieu, the command of entrepreneurs over the lives of their employees was next to absolute and involved the domination of their voting behavior, too. For instance, Joe Perriello, an Italian-American worker of the Jones and Laughlin Steel Company in Aliquippa, Pennsylvania, has recalled that, in the 1920s, " if you wanted to work, if you wanted to eat, if you wanted to have something, you had to be Republican » (as quoted in Green 8). Another resident of Aliquippa of Italian descent, Maurilio Bagaglini, wrote presidential candidate Roosevelt as late as 1932 that "we cannot even mention your name unless we want to end up in jail.» Supervisors and foremen usually threatened laborers with dismissal, eviction from company-owned housing, and end of credit at company-controlled stores unless they went against their class interests and cast their ballots for GOP candidates. Indeed, a Democratic worker from Windber, a company town of the Berwind-White Coal Mining Company in western Pennsylvania, contended that his community had «never gone Democratic " before 1932 because "our little town is owned and operated by one company [...] [which] issues orders for the support of the [Republican] opponent " (Sharkery). Actually, in Windber, Berwind-White supervisors not only drove coal miners to the polling stations on election days, but they even insisted on entering the voting booths to show them how to mark their ballots for the GOP (Beik 327-28).

9 It is, therefore, hardly surprising that, in company towns, the necessity to protect one's job by appeasing employers in the party choice at the polls prevailed on ethnic and class issues in shaping Italian Americans' voting behavior longer than elsewhere. For example, incumbent Republican President Herbert Hoover carried Windber's eastern ward, which was home to the largest Italian-American settlement in town, by 60.2 percent of the vote as late as 1932. In that year, Hoover even obtained a 84-percent landslide in the « Little Italy » of Carbondale, a small town in Pennsylvania where about eighty percent of the residents of Italian descent in the laborforce held unskilled jobs in coal mines, in silk mills or in railroad companies (Pennsylvania Manual, 1933).

10 Corporate political interference affected the Italian-American vote in large cities, too. But the wider array of job opportunities than those available in company towns made 
members of Italian-American communities in metropolitan America freer to desert the GOP on particular occasions. Regardless of the ethnic appeal of his candidacy, Smith failed to win a plurality among Italian Americans in Windber and Carbondale in 1928 and Hoover carried both «Little Italies » by 60.2 percent and 64.9 percent of the vote, respectively. On the contrary, 56.9 percent of Philadelphians of Italian descent cast their ballots for Smith in 1928 (Pennsylvania Manual, 1929). Similarly, between 1924 and 1928, the Italian-American vote for the Democratic party jumped from 31 percent to 63 percent in Chicago (Allswang 42) and from 48 percent to 77 percent in New York City (Burner 236).

11 Moreover, the existence of a large number of self-employed or skilled workers within some specific Italian-American communities allowed many of their members to avoid being coerced into supporting the GOP in the pre-Depression decade. A powerful Republican machine dominated politics in Providence, Rhode Island, before 1935 (M. J. Smith). Yet the local Italian-American electorate leaned toward the Democratic party in the 1920s. The Democratic standard-bearer won 60.6 percent of the Italian-American vote in 1922, 49.8 percent-with an additional 4.5 percent going to La Follette-in 1924, 64.1 percent in 1926, and even 78.1 percent in 1928 (Providence Journal Almanac, 1923, 1925, 1927, 1929). A significant number of jewelry workers, independent tailors, and storeowners had reduced to less than 60 percent the percentage of common and unskilled manufacturing laborers by 1915 (Shipee 278). As the size of these two latter categories further declined in the following years, so did the number of eligible voters who were potentially prone to political intimidation (Colangelo $40 ; \mathrm{J}$. E. Smith 41 ). The Republican machine was obviously unable to pressure self-employed tailors into voting for the candidate of the GOP by threat of dismissal if they cast their ballots for the Democratic party. Such was the case of the shopkeepers, bakers, and barbers, who could rely on their fellow ethnics' loyalty to stay in business regardless of their own partisan affiliation. Likewise, the political coercion of jewelry workers must have failed to be particularly effective because the industries of the sector could not afford high turnovers caused by political reasons (they needed a skilled labor force that was almost impossible to replace overnight at little or no cost for production). These kinds of occupations supplied Italian-American workers with political independence since such categories of voters did not have to rely on the Republican machine to secure or retain employment. It is no accident if the organizer of Providence's 1928 Italian-American Smith for President Club, Salvatore Pastore, was a talented independent women's tailor (Morgenthau 14, 20).

Significantly, in Providence, the support of the Italian-American electorate for the Democratic party was larger in the 1920s than during the subsequent decade. Roosevelt received 75.5 percent of the vote in 1932 and 74.2 percent in 1936 as opposed to Smith's 78.1 percent in 1928 (Providence Journal Almanac, 1929, 1933, 1937). The Depression hit Providence hard. The year 1933 witnessed 77,000 workers march through the city's downtown area in support of Roosevelt's labor and social legislation (Stanton 8). Yet, while relief jobs with federal agencies such as the Works Progress Administration (WPA) could easily equal pre-Depression unskilled positions, they could hardly match skilled occupations in the jewelry industry.

In Philadelphia, a majority of Italian Americans went back to the GOP in 1932 and Hoover obtained 52.5 percent of their vote (Pennsylvania Manual, 1933). In hard times, many destitute members of the local community relied on the services of the city's 
Republican organization to cope with the economic crisis. Indeed, boss Vare's henchmen operated relief kitchens to supply the needy with food. They also established welfare committees that offered Republican stalwarts free health care, clothing, and coal besides paying utilities bills on their behalf (Bauman 54-55). Only the enactment of the social and labor legislation of the New Deal managed to align a majority of the Italian-American electorate with the Democratic party in federal and state elections in Philadelphia and left Roosevelt with 65.1 percent of the vote in this community in 1936 (Pennsylvania Manual, 1937).

Conversely, the demise of the Republican machine in Pittsburgh for lack of funds and patronage jobs within three years from the beginning of the Depression (Weber 45-46, 51-52) enabled Roosevelt to carry this latter city's « Little Italy " by 62 percent of the vote as early as 1932 (Pennsylvania Manual, 1933). Likewise, the collapse of Chicago's Republican organization in the wake of Mayor William Hale «Big Bill» Thompson's 1931 defeat to his Democratic challenger Anton J. Cermak witnessed the consolidation of the Italian-American vote for the Democratic party in presidential elections (Gosnell 10-14). Chicago's community cast as much as 53 percent of its ballots for Thompson in 1931 despite the identification of the GOP with the economic crisis since many of its members still relied on the political services of the incumbent mayor's machine. Yet Italian-American support for the Democratic presidential candidate increased from 63 percent in 1928 to 64 percent in 1932 (Allswang 42).

Widespread unemployment during the Depression also freed Italian Americans from the control of their employers in company towns. Obviously, prospective voters with no job could not be threatened with dismissal. In Vandergrift, Pennsylvania, the model settlement of the American Sheet and Tin Plate Company, Hoover carried the 5th ward, where a majority of the local residents from Italian background lived, with 64.9 percent of the vote in 1928. But Roosevelt received 55 percent of the ballots cast four years later. Even Windber's Italian-American community eventually went Democratic by 64.5 percent of the vote in 1934 (Pennsylvania Manual, 1929, 1933, 1935).

In Trenton, too, former employees of the John A. Roebling and Sons who were out of work in the 1930s cast their ballots for the Democratic party. As a result, Roosevelt carried the ward that was home to Trenton's « Little Italy » by 77.5 percent in 1932 and by 83.6 percent in 1936 (Peroni 74-75).

The Irish monopoly of positions in the Democratic hierarchy and hold of most candidacies on the tickets of this party made an additional contribution to the Republican allegiance of many Italian Americans in the pre-Depression decades. The perception of their marginalization within the Democratic party led many Italian Americans into the Republican camp (Alba 86). Most notably, New York City's Fiorello H. La Guardia joined the GOP to launch his successful political career because he realized that his ethnic ancestry was a liability in scaling the Irish-dominated Democratic ranks (Kessner 31).

18 Yet the 1930s also witnessed a significant extension of the award of political recognition for Italian Americans on the part of Democratic officials on both the local and national levels. As for this latter arena, for instance, President Roosevelt appointed Matthew Abruzzo to a federal judgeship in 1936 and made him the first Italian American to hold such a position (Bayor 36). Likewise, in local politics, an increasing number of candidates of Italian ancestry began to secure unprecedented nominations for elective offices for the Democratic party. Rhode Island's gubernatorial hopeful 
Theodore Francis Green personally handpicked Louis Cappelli, a lawyer of Italian descent, as his running mate for secretary of state in 1930 (Levine 119). Four years later, Democratic officials in Pittsburgh slated Frank Zappala for the Pennsylvania House of Representatives (Unione 22 June 1934). In 1936, Philadelphia's Democratic City Committee even persuaded William Hagen, who had won the nomination for the State Senate in the city's largely Italian-American first district in the primary elections, to withdraw in order to replace him with Anthony Di Silvestro, the editor of the local Italian-language weekly La Libera Parola (12 Sept. 1936).

The reason for slating Italian-American candidates was to lure their fellow-ethnic voters into casting their ballots for the Democratic party out of ethnic solidarity. Such a strategy usually proved successful. In South Philadelphia's "Little Italy, » it was Roosevelt who ran on Di Silvestro's coattails in 1936. The President received 65.1 percent of the Italian-American vote, as opposed to Di Silvestro's 69.9 percent (Manual of the City Council 288). So did Democratic senatorial candidate Joseph F. Guffey with Zappala in Pittsburgh's Italian-American districts in 1934. Actually, while Guffey won 69.9 percent of the Italian-American vote, Zappala carried his own ethnic community by 83.4 percent (Allegheny County).

Many Italian Americans benefited from the labor legislation of the New Deal. Section 7a of the 1933 National Industrial Recovery Act (NIRA) enabled radio workers and bricklayers of Italian descent to establish their own unions in Philadelphia (Jarrell 43-45 ; Scranton and Licht 237). It also spurred a significant growth in the membership of the United Mine Workers of America in the coal towns of western Pennsylvania from which the union had been previously barred and, as Italian-American labor organizer John Ghizzoni put it, let his fellow ethnics « feel that they are once more free men » (as quoted in Johnson 123). In addition, the NIRA made possible a significant increase in the minimum wage of jewelry workers in Providence from fifteen or twenty cents an hour to thirty-five cents and shortened their workweek to forty hours (DeCredico 33; Frank Santopietro as quoted in Weisberg 138). Italian Americans also swelled the ranks of the Amalgamated Clothing Workers of America in Philadelphia and joined the Steel Workers Organizing Committee (SWOC) in western Pennsylvania in the wake of the passing of the 1935 Wagner Act-a key piece of legislation in the construction of the New Deal's political order (Plotke)-that reintroduced workers' right to organize and to bargain collectively after the Supreme Court had declared the NIRA unconstitutional (Passero 301-2, 313, 337 ; Bodnar 122, 127-28, 182). At the same time, the Congress of Industrial Organizations (CIO) began to make inroads into Providence's Italian-American workforce in textile mills (Al Sisti as quoted in Buhle 36). In Pittsburgh, too, as Italian Americans have recalled, "when the union came [...], Roosevelt was the one who started all that » (Borgna).

Gennaro Di Biase, a second-generation Italian American from Providence, has recalled that his father became a « loyal Democrat » because « the New Deal was pretty good for workers. » Grateful to Roosevelt for the achievements of the labor unions during his first term, Italian-American workers not only voted for the incumbent president in 1936, but they were also active in his re-election campaign. Angelo Volpe, Domenic Brandy, and other labor organizers from Italian background established a Democratic Social Club in Aliquippa as early as 1934 (Green 13-14, 18). They made a significant contribution to Roosevelt's smashing success over Republican Alfred M. Landon in a town that Hoover had easily carried in 1932, when the elections had once again taken 
place under heavy political intimidation of workers on the part of the Jones and Laughlin Steel Company (Evans). Likewise, the Labor's Non-Partisan League of Pennsylvania included numerous activists of Italian descent who operated to mobilize their fellow-ethnic workers for the Democratic ticket in 1936 (United Mine Workers of America; Spencer).

In Baltimore, too, the New Deal encouraged Italian Americans to get involved in labor unions. They included such local working-class leaders as Victor Zappacosta, Joe D'Annunzio, Pasquale Piersanti, and Ulisse De Dominicis. The latter became the chairperson of the city's Joint Board of the Amalgamated Clothing Workers of America. As the CIO-affiliated Baltimore Industrial Council-in which De Dominicis and his union enjoyed considerable influence-campaigned hard for the Democratic party in 1936, Roosevelt polled 86 percent of the Italian-American vote (Argersinger 153, 157-58, 191). However, the cooperation between labor unions and the Democratic party was not always essential in order to enable Roosevelt to carry Italian-American communities. Chicago offers a case in point. Workers of Italian ancestry bulked large in the membership of this city's SWOC, an organization that did its best to accommodate ethnic minorities (Cohen 306, 309, 337-39). One of them, Nicholas Fontecchio, served as director of District 31, which embraced the whole Chicago-Calumet region, from the establishment of this union in 1936 to 1940. Another, Joseph Germano, was president of local 1008 in 1936, became sub-district director for the Indiana Harbor area the following year, and replaced Fontecchio in 1940. Chicago's Democratic machine was hostile to the SWOC until 1937 because the union seemed too radical in the eyes of bosses with a background as businessmen and property owners (Slayton). Such antipathies, however, did not prevent Italian Americans from strengthening their majority for Roosevelt between 1932 and 1936 (Allswang 44).

Italian Americans also profited from the relief measures of the Roosevelt administration nationwide. Their presence among the foremen of WPA projects was so disproportionately high in Pittsburgh in the mid 1930s that it stirred up the protest of the members of other ethnic minorities (McRoberts 31-34). Moreover, roughly one third of the heads of family in the main area of Philadelphia's Italian-American settlement were on federal relief in 1936 (Maiale 170). Likewise, Providence's predominantly Italian 13th ward totaled more relief cases than any other ward in the city (Davies 96). Actually, reliance on WPA jobs during the economic crisis is a leitmotif in local Italian Americans' recollections about the Depression (Raponi 3 ; De Nucci 5).

Still machine politics continued to influence Italian Americans' voting behavior in the New Deal years as well. The Democratic party exploited the federal patronage that the capture of the White House had made available in order to establish powerful organizations that replaced Republican machines in such pre-Depression bailiwicks of the GOP as Pittsburgh and Providence (Stave ; Weber 65-105). Residents of Pittsburgh's Lower Hill district-the site of one of the largest Italian-American settlements in the city-had to have the Democratic leader of their ward consent to their appointment to jobs with the WPA. Italian-American ward leaders John Verona and Charles Papale became political powers as the dispensers of patronage among their fellow ethnics on behalf of Democratic boss David L. Lawrence's machine (Pittsburgh Post-Gazette, 14 Apr., 17 Oct. 1936 ; Pittsburgh Press, 12 Jan. 1937). Similarly, 13th ward's Alderman Thomas F. Luongo allegedly controlled about 15,000 Italian-American votes in Providence by distributing the jobs that Theodore Francis Green's Democratic organization held as 
part of its federal and state political spoils (Federal Bureau of Investigation). As the percentage of Italian Americans working on government projects increased from 3 percent to 11.3 percent in the North End and from 5 percent to 11.3 percent in East Boston between 1934 and 1940, the brokerage of Democratic politicians was necessary to obtain positions with the WPA in Boston, too (Trout 177; Whyte, 197). Likewise, Italian-American WPA applicants in Philadelphia needed a letter of recommendation from their Democratic ward leader (Evening Bulletin, 23 Apr. 1936).

As Rhode Island's Democratic chairperson J. Howard McGrath pointed out on the eve of the 1936 presidential contest, the chances of carrying Providence's Italian-American community were high because «the Democrats have given many good positions to Italo-Americans. » However, this phenomenon was not confined to Providence only. In Chicago, constituents with Italian-sounding names like Carradina and Memenga conceived their Democratic vote as part of a quid pro quo to such an extent that they asked Roosevelt for relief assistance on the grounds of their support for the president at the polls and even threatened not to cast their ballots for him again unless their benefits increased (Cohen 258). Likewise, Rose Marzucca from Centredale, Rhode Island, expected Roosevelt to "give us some work " because she and her family « have always been Democrats." After all, in Utica, New York State, it was primarily the establishment of an influential organization under the leadership of Rufus Elefante which accounted for the 74 percent of the vote that Roosevelt received in the local "Little Italy » in 1936. The consolidation of Elefante's machine let the president retain a 63-percent majority among Utica's Italian Americans in 1940 (Schiro 138-39; Bean 509).

Actually, patronage did not only consolidate the Democratic allegiance of Italian-American voters in the mid 1930s. It also helped keep them in the Democratic camp in spite of their increasing dissatisfaction with Roosevelt's foreign policy at the end of the decade. As the president's anti-Fascist feelings became more and more blatant and reached a climax with his stigmatization of Italy's entry into World War II on 10 June 1940 through the infamous metaphor «the hand that held the dagger has stuck it in the back of its neighbor " (Roosevelt 9:263), many Italian Americans distanced themselves from Roosevelt. Although most of them disavowed fascism following Italy's declaration of war on France, they were also afraid that the president's antagonistic attitude toward Benito Mussolini's regime would eventually result in a military conflict between the United States and their mother country, where they still had relatives and friends (De Conde 237-41).

Republican propaganda played on such fears in the effort to secure the Italian-American vote nationwide for GOP presidential candidate Wendell Willkie. It portrayed the election for the White House as a sort of referendum between the maintenance of American neutrality and the participation of the United States in the conflict against Germany and Italy. As Philadelphia's pro-Republican Italian-language daily Il Popolo Italiano contended, «a vote for Roosevelt is a vote for war. A vote for Willkie is a vote for peace » (29 Oct. 1940). Similarly, in Providence, the Rhode Island Echo, an Italian-American weekly owned by Republican Vincent Sorrentino, depicted Roosevelt as a warmonger who would drag the United States into a war against Italy in case of reelection while portraying Willkie as a balanced statesman who would take a peaceful road (11, 25 Oct. 1940). In Chicago, too, Republican State Senator Eliodor 
Libonati urged Italian Americans «to vote against Roosevelt » because the president was against their ancestral country (Sereno).

Yet the existence of effective Democratic organizations curbed Italian Americans' defection to the GOP. Conversely, the decrease in the Italian-American vote for Roosevelt between 1936 and 1940 was particularly significant in those cities where the local Democratic urban machines were weak. The president managed to poll 74 percent of the ballots in the Pittsburgh community that Lawrence's organization still mastered (Pennsylvania Manual, 1941). Furthermore he received 62.9 percent of the vote in the Italian-American neighborhoods in East Boston and 51.1 percent in the North End, in a city where Mayor Maurice Tobin had aptly exploited the federal patronage to retain his hold over the bulk of the ethnic electorate (Gamm 83; Lapomarda). Roosevelt also polled 68.3 percent of the vote in Providence (Providence Journal-Bulletin Almanac, 1941). By contrast, support for the GOP rose from 9 percent to 42 percent in San Francisco's «Little Italy » (Wirt 235). Roosevelt even lost its prewar majority of New York City's Italian-American electorate as his vote fell from 79 percent to 42 percent (Bayor 147). Remarkably, both San Francisco and New York had Republican administrations, although the latter city's mayor, Fiorello H. La Guardia, was a supporter of the president (Kessner 480-82). Even if San Francisco held non-partisan municipal elections, Mayor Angelo Rossi was an « Old Guard Republican » (Issel 78).

As further evidence of the part that political patronage played in keeping voters of Italian extraction within the Democratic ranks, most Italian-American residents of Boston's North End who still had a favorable opinion of Roosevelt after their ancestral land entered World War II were also the recipients of federal relief (J. S. Smith 589). Likewise, in Philadelphia's Italian-American neighborhoods, the slump in the vote for the president between 1936 and 1940 was highest were relief rates were lowest. In the Italian districts of the 34th ward, in which only 1.9 percent of Italian Americans were on relief in 1940, support for Roosevelt fell by 17.5 percent. But the decrease was 8.3 percent in the Italian-American areas of the 3rd ward, where 4.4 percent of the workers from Italian background held federal emergency jobs (Pennsylvania Manual, 1941). In New York City, too, although Roosevelt failed to carry the Italian-American community in 1940, he received his largest electoral following among its members in lower-class districts, where residents were more likely to be on federal relief than their fellow ethnics in more affluent neighborhoods. Actually, 44.3 percent of Italian Americans who lived in lower-class voting districts cast their ballots for Roosevelt as opposed to 39.3 percent of dwellers of middle-class areas (Bayor 148).

31 A comparison of the voting behavior of Philadelphia's Italian Americans in federal and local elections sheds additional light on the pivotal role of political patronage in cementing their participation in the Roosevelt coalition. The Democratic party carried the community in all federal and state contests from 1934 through 1940. Nonetheless a majority of the city's Italian-American voters retained their pre-Depression Republican attachment in all county and municipal races except for 1937. Since the Democratic party failed to elect a mayor throughout the interwar years and managed to win only the 1933 county elections, a Republican machine survived thanks to the hold of city and county spoils until the postwar years. As a result, Italian Americans continued to rely on the GOP for access to local patronage and went Democratic in local elections only in 1937, when both the offices the Democrats had gained four years earlier and their political spoils were at stake (City of Philadelphia, 1930-41). 
32 A similar divergence of Italian Americans' party choice in local races from their alignment in federal contests occurred in Cleveland, Ohio, too. The Depression witnessed a shift of allegiance of this city's «Little Italy " from the GOP to the Democratic party in presidential and Congressional elections (Ferroni 3). Yet most Italian Americans remained loyal to fellow-ethnic Republican Alexander De Majoribus when they cast their ballots for the City Council. A member of this latter body since 1928 as the representative of the 19th ward, the heart of Cleveland's Italian-American community, De Majoribus used his prominence in local politics to procure employment for his constituents and exploited their indebtedness to their councilman in order to retain his seat through 1947 (Veronesi 250-51, 307).

Likewise, in the 1930s, New York City's Italian Americans went Democratic in the presidential elections, but Republican in the mayoral contests. Roosevelt polled 80.5 percent of their vote in 1932 and 78.7 percent in 1936. Nonetheless La Guardia received 62.2 percent of the ballots of his fellow ethnics in 1933 and 62.6 percent in 1937 (Bayor $130,137,147)$. Although La Guardia's ancestry helped him secure the backing of the Italian-American electorate, so did his political machine and patronage. Similarly, in San Francisco, Italian Americans cast their ballots for Democratic Roosevelt in the races for the White House, while-at the local level-they supported Republican Rossi, a talented political broker who not only profited from his own Italian descent but also benefited from his hold of municipal jobs (Mormino and Pozzetta 148).

In conclusion, the creation of a Democratic majority among Italian Americans foreran the economic crisis in Democratic strongholds. Instead, in pre-Depression Republican bailiwicks, the aftershocks of the economic crisis, the labor and social legislation of the New Deal, the growth of political recognition by Democratic officials as well as the political patronage that Roosevelt's 1932 election to the White House made available to the Democratic party added to Smith's 1928 ethnic appeal in establishing a Democratic majority among Italian Americans during the 1930s. However, the persistence of pro-Republican political coercion of voters on the part of their employers into the early 1930s and the survival of urban machines of the GOP delayed Italian Americans' adherence to the Roosevelt coalition or curbed their participation in the Democratic majority even in the heyday of the New Deal. Likewise, the existence of powerful Democratic organizations helped keep Italian-American voters in the Democratic column in the face of the erosion of the Roosevelt majority in the late 1930s.

Political scientist Robert Lane once argued that « the seat of ethnic politics is the local community " (239). The late Democratic Speaker Tip O'Neal similarly remarked that " all politics is local. » The timing and extent of Italian Americans' participation in the New Deal coalition were no exception to this pattern.

\section{BIBLIOGRAPHIE}

ALBA, Richard. Italian Americans : Into the Twilight of Ethnicity. Englewood Cliffs, NJ : Prentice-Hall, 1985. 
ALLEGHENY COUNTY, Department of Elections. Allegheny County Voting Records : U. S. Senator and Representatives in the General Assembly. 1934. Archives of Industrial Society, U of Pittsburgh.

ALLSWANG, John M. A House for All Peoples : Ethnic Politics in Chicago, 1890-1936. Lexington : UP of Kentucky, 1971.

ARGERSINGER, Jo Ann E. Toward a New Deal in Baltimore : People and Government in the Depression. Chapel Hill : U of North Carolina P, 1988.

BAGAGLINI, Maurilio. Letter to Franklin D. Roosevelt. 3 Nov. 1932. Papers of the National Committee of the Democratic Party, box 689. Franklin D. Roosevelt Lib., Hyde Park, NY.

BAGBY, Wesley M. The Road to Normalcy: The Presidential Campaign and Election of 1920. Baltimore : Johns Hopkins UP, 1968.

BARONE, Michael. «Italian Americans and Politics. » Italian Americans : New Perspectives in Italian Immigration and Ethnicity. Ed. Lydio F. Tomasi. Staten Island, NY : Center for Migration Studies, 1985. 378-84.

BAUMAN, John F. « The City, the Depression, and Relief : The Philadelphia Experience, 1929-1939. » Diss., Rutgers U, 1969.

BAYOR, Ronald H. Neighbors in Conflict : The Irish, Germans, Jews and Italians of New York City, 1929-1941. Baltimore : Johns Hopkins UP, 1978.

BEAN, Philip Albert. « Fatherland and Adopted Land : Irish, German, and Italian-American Nationalism (1865-1950). » Diss., U of Rochester, 1994.

BEIK, Mildred Allen. The Miners of Windber. University Park, PA : Pennsylvania State UP, 1996.

BLODGETT, Geoffrey. « Yankee Leadership in a Divided City : Boston, 1860-1910. » Journal of Urban History 8 (1982) : 371-96.

BODNAR, John. Workers' World : Kinship, Community, and Protest in an Industrial Society, 1900-1940. Baltimore : Johns Hopkins UP, 1982.

BORGNA, Lucia Tosco. Interview. 26 Feb. 1977, 20, Ethnic Fraternal Organizations Oral History Project, box 1. Archives of Industrial Society, U of Pittsburgh.

BUHLE, Paul, ed. Working Lives : An Oral History of Rhode Island Labor. Providence : Rhode Island Historical Society, 1987.

BURNER, David. The Politics of Provincialism : The Democratic Party in Transition, 1918-1932.

Cambridge, MA : Harvard UP, 1967.

CITY OF PHILADELPHIA. Annual Reports of the Registration Commission. 12 vols. Philadelphia : Dunlap, 1930-41.

COHEN, Lizabeth. Making a New Deal : Industrial Workers in Chicago, 1919-1939. New York : Cambridge UP, 1990 .

COLANGELO, John P. «Italians in Providence, 1900-1930. » Honor thesis, Brown U, 1974.

DAVIES, David L. « Impoverished Politics : The New Deal's Impact on City Government in Providence. » Rhode Island History 42 (1983) : 86-100.

DeCREDICO, Jessan Dunn. « Josephine DeCredico. » Mirror 3 (1977) : 31-34.

De CONDE, Alexander. Half Bitter, Half Sweet : An Excursion into Italian-American History. New York : Charles Scribner's Sons, 1971. 
De NUCCI, Evelyn Cavallaro. Interview. 5 Dec. 1990, 5. World War II Interviews Collection, Rhode Island Historical Society, Providence.

Di BIASE, Gennaro. Interview. 22 Jan. 1985, Rhode Island Labor History Project, tape C-8, Rhode Island Historical Society, Providence.

DUFF, John B. « The Italians. » The Immigrants' Influence on Wilson's Peace Policies. Ed. Joseph P. O'Grady. Lexington : UP of Kentucky, 1967. 111-39.

EVANS, Benjamin C. L. Letter to Franklin D. Roosevelt. 15 Sept. 1932. Papers of the National Committee of the Democratic Party, box 655. Franklin D. Roosevelt Lib., Hyde Park, NY.

FASCE, Ferdinando. Una famiglia a stelle e strisce : Grande Guerra e cultura d'impresa in America. Bologna : il Mulino, 1983.

FEDERAL BUREAU OF INVESTIGATION. Report. 14 July 1942. Department of Justice, Record Group 60, Classified Subject File, 146-6-95, box 53. National Archives II, College Park, MD.

FERRONI, Charles D. The Italians in Cleveland : A Study in Assimilation. New York : Arno, 1980.

GAMM, Gerald H. The Making of New Deal Democrats : Voting Behavior and Realignment in Boston, 1920-1940. Chicago : U of Chicago P, 1989.

GARRONI, Maria Susanna. «Immigrati e cittadini : L'essere 'americani' degli italoamericani tra Otto e Novecento. » Contemporanea 5 (2002) : 32-49.

GOSNELL, Harold F. Machine Politics : Chicago Model. 1937 ; New York : AMS, 1969.

GREEN, James. « Democracy Comes to 'Little Siberia' : Steel Workers Organize in Aliquippa, Pennsylvania, 1933-1937. » Labor's Heritage 5 (1993) : 6-27.

ISSEL, William. « New Deal and Wartime Origins of San Francisco's Postwar Political Culture : The Case of Growth Politics and Policy. » The Way We Really Were : The Golden State in the Second Great War. Ed. Roger W. Lotchin. Urbana : U of Illinois P, 2000. 68-92

JARRELL, Donald Winifield. «A History of Collective Bargaining at the Camden-Area Plants of the Radio Corporation of America. » Diss., U of Pennsylvania, 1967.

JEANSONNE, Glen. Messiah of the Masses : Huey P. Long and the Great Depression. New York : HarperCollins, 1993.

JENSEN, Richard J. « The Structure of the Democratic Coalition, 1936-1948. » Paper presented at the conference of the Social Science Historical Association, Chicago, 20 Nov. 1998.

JOHNSON, James P. «Reorganizing the United Mine Workers of America in Western Pennsylvania during the New Deal, » Pennsylvania History 37 (1970) : 117-32.

KESSNER, Thomas. Fiorello H. La Guardia and the Making of Modern New York. New York: McGraw-Hill, 1989.

LANE, Robert E. Political Life: Why People Get Involved in Politics. Glencoe, IL : Free P, 1959.

LAPOMARDA, Vincent A. « Tobin, Maurice Joseph. » Biographical Dictionary of American Mayors, 1820-1980 : Big City Mayors. Ed. Melvin G. Holli and Peter d'A. Jones. Westport : Greenwood Press, 1981.365.

LEVINE, Erwin L. Theodore Francis Green : The Rhode Island Years, 1906-1936. Providence : Brown UP, 1963.

LUBELL, Samuel. The Future of American Politics. 1951. New York : Harper \& Row, 1965. 
MAIALE, Hugo V. « The Italian Vote in Philadelphia between 1928 and 1946. » Diss., U of Pennsylvania, 1950.

Manual of the City Council of the City of Philadelphia for 1937. Philadelphia : Dunlap, 1937.

MARTELLONE, Anna Maria. «Italian Immigrants, Party Machines, Ethnic Brokers in City Politics, from the 1880s to the 1930s. » The European Emigrant Experience in the U.S.A. Ed. Walter Hölbling and Reinhold Wagnleitner. Tübingen : Gunter Narr Verlag, 1992. 171-87.

MARTELLONE, Anna Maria. Una Little Italy nell'Atene d'America : La comunità italiana di Boston dal 1880 al 1920. Naples : Guida, 1973.

MARTINELLI, Phyllis Cancilla. «Italian-American Experience. » America's Ethnic Politics. Ed. Joseph S. Roucek and Bernard Eisenberg. Westport : Greenwood, 1982. 217-31.

MARZUCCA, Rose. Letter to Franklin D. Roosevelt. N.d. [but Nov. 1932]. Papers of the National Committee of the Democratic Party, box 704, Franklin D. Roosevelt Lib., Hyde Park, NY.

McGRATH, J. Howard. Letter to James A. Farley. 28 Oct. 1936. J. Howard McGrath Papers, box « Democratic Party National Committee, 1935-1949, » folder « James A. Farley, 1936. » Phillips Memorial Lib., Providence College, Providence.

McROBERTS, Agnes Maybeth. «Attitudes and Family Situations of Thirty Works Progress Administration Employees. » M.A. thesis, U of Pittsburgh, 1938.

MORGENTHAU, Ruth S. Pride Without Prejudice: The Life of John O. Pastore. Providence : Rhode Island Historical Society, 1989.

MORMINO, Gary Ross. Immigrants on the Hill : Italian-Americans in St. Louis, 1882-1982. Urbana : U of Illinois P, 1986.

MORMINO, Gary Ross, and George E. POZZETTA, «Ethnics at War : Italian Americans in California during World War II. » The Way We Really Were : The Golden State in the Second Great War. Ed. Roger W. Lotchin. Urbana : U of Illinois P, 2000. 143-63.

MOTT, James C. « The Fate of an Alliance : The Roosevelt Coalition, 1932-1952. » Diss., U of Illinois-Chicago, 1988.

MURRAY, Lawrence L. « The Mellons, Their Money, and the Mythical Machine. » Pennsylvania History 42 (1975) : 221-41.

O’NEIL, Tip. All Politics Is Local and Other Rules of the Game. New York : Times Books, 1994.

PASSERO, Rosara Lucy. « Ethnicity in the Men's Ready-Made Clothing Industry, 1880-1950 : The Italian Experience in Philadelphia. » Diss., U of Pennsylvania, 1978.

Pennsylvania Manual. 7 vols. Harrisburg : Commonwealth of Pennsylvania, 1929-41.

Pennsylvania State Manual. 2 vols. Harrisburg : Commonwealth of Pennsylvania, 1925-27.

PERONI, Peter A. The Burg : An Italian-American Community at Bay in Trenton. Lanham, MD : UP of America, 1979.

PLOTKE, David. Building a Democratic Political Order : Reshaping American Liberalism in the 1930s and 1940s. New York : Cambridge UP, 1996.

Providence Directory and Rhode Island Business Directory. 4 vols. Providence : Sampson \& Murdock, 1922-28.

Providence Journal Almanac. 18 vols. Providence : Providence Journal, 1923-40.

Providence Journal-Bulletin Almanac. Providence : Providence Journal-Bulletin, 1941. 
RAPONI, Serafino. Interview. 12 July 1984. Rhode Island Labor History Project. Rhode Island Historical Society, Providence.

ROOSEVELT, Franklin D. The Public Papers and Addresses of Franklin D. Roosevelt. Ed. Samuel I. Rosenman, 13 vols. New York : Macmillan, 1938-50.

ROTHENBERG, Stuart, Eric LICHT, and Frank NEWPORT. Ethnic Voters and National Issues. Washington, DC : Free Congress Research and Education Foundation, 1982.

SALTER, John T. The People's Choice : Philadelphia's William S. Vare. New York : Exposition, 1971.

SCRANTON, Philip, and Walter LICHT. Work Sights : Industrial Philadelphia, 1890-1950. Philadelphia : Temple UP, 1986.

SCHIRO, George. Americans by Choice : History of the Italians in Utica. N.p. : privately printed, 1940.

SERENO, Renzo. Letter to Eugene Katz. 27 Oct. 1942. Philleo Nash Papers, box 23, folder «Italian-American Memoranda. » Harry S. Truman Lib., Independence, MO.

SHARKERY, John G. Letter to Franklin D. Roosevelt. 31 Oct. 1932. Papers of the National Committee of the Democratic Party, box 668. Franklin D. Roosevelt Lib., Hyde Park, NY.

SHIPPEE, Lester Burrell. « Some Aspects of the Population of Providence. » State of Rhode Island. Report of the Commissioner of Labor Made to the General Assembly for the Years 1916-1917-1918-1919. Providence : Freeman, 1921. 207-84.

SLAYTON, Robert A. « Labor and Urban Politics : District 31, Steel Workers Organizing Committee, and the Chicago Machine. » Journal of Urban History 23 (1996) : 29-65.

SMITH, Jeanette Sayre. « Broadcasting for Marginal Americans. » Public Opinion Quarterly 6 (1942) : 588-603.

SMITH, Judith E. Family Connections : A History of Italian and Jewish immigrant Lives in Providence, Rhode Island, 1900-1940. Albany : State U of New York P, 1985.

SMITH, Matthew J. « The Real McCoy and the Bloodless Revolution of 1935. » Rhode Island History 32 (1973) : 67-85.

SPENCER, Thomas T. «'Labor is With Roosevelt' : The Pennsylvania Labor Non-Partisan League and the Election of 1936. » Pennsylvania History 46 (1979) : 3-16.

STANTON, Mike. The Prince of Providence. New York : Random House, 2003.

STAVE, Bruce M. The New Deal and the Last Hurrah : Pittsburgh Machine Politics. Pittsburgh : U of Pittsburgh P, 1970.

TROUT, Charles H. Boston, the Great Depression, and the New Deal. New York : Oxford UP, 1977.

UNITED MINE WORKERS OF AMERICA. Papers of District 2, box 111, folder 205. Special

Collections. Indiana U of Pennsylvania, Indiana, PA.

U. S. BUREAU OF THE CENSUS. 16th Census of the United States : Population and Housing, Statistics for Census Tracts, Philadelphia. Washington : U.S. Government Printing Office, 1942.

VERONESI, Gene P. Italian Americans and Their Communities of Cleveland. Cleveland : Cleveland State UP, 1977.

WEBER, Michael P. Don't Call Me Boss : David L. Lawrence, Pittsburgh's Renaissance Mayor. Pittsburgh : U of Pittsburgh P, 1989.

WEISBERG, Naida D., ed. Diamonds Are Forever, but Rhinestones Are for Everyone : An Oral History of the Costume Jewelry Industry of Rhode Island. Providence : Providence Jewelry Museum, 1999. 
WILLIAMS, Frederick W. « Recent Voting Behavior of Some Nationality Groups. » American Political Science Review 40 (1946) : 528-32

WHYTE, William F. Street Corner Society. Chicago : U of Chicago P, 1955.

WIRT, Frederick M. Power in the City : Decision Making in San Francisco. Berkeley : U of California P, 1974.

INDEX

Keywords : New Deal, 1920-1940, Italian-Americans, voting behavior, political parties Mots-clés : Italo-Américains, sociologie électorale, partis politiques

\section{AUTEUR}

\section{STEFANO LUCONI}

University of Florence, Italy 